\title{
CHILD REARING PRACTICES AMONGST BROTHEL BASED COMMERCIAL SEX WORKERS
}

\author{
GEETA PARDESHI, S. BHATTACHARYA*
}

\section{ABSTRACT}

BACKGROUND: The experiences of the commercial sex workers as they fulfill the role of being a parent, have rarely been reported. Considering their socioeconomic background, profession and work pattern, the women are bound to face major challenges. AIMS: To describe child bearing, family support, dietary practices and various placement options for raising children. STUDY DESIGN: A cross-sectional descriptive study of brothel- based commercial sex workers. STATISTICAL ANALYSIS: $X^{2}$ test, Fisher's Exact test RESULTS: Some commercial sex workers continued pregnancy with the hope of security and support, while others were compelled to do so, as they report late for medical termination of pregnancy. A group of sex workers (Devdasis) received support during pregnancy, delivery, puerperium and child-rearing. The role and responsibilities of raising the child, depended upon the kind of family support available to the mothers. Being a single parent, stigma of the profession, odd working hours and variable family support were major challenges, while the fact that the women were earning, availability of rehabilitation centers, the homogeneous groups within the brothels, supportive peers and local non governmental organizations were factors which helped them in the process of raising their children. CONCLUSIONS: Day care centers and night shelters should be opened up in the red light area where the children can be looked after, during the working hours. The sex workers should be educated about weaning and nutrition. The role of peer workers and NGOs was very important in helping the women raise their children.

Key words: Child rearing or child xare or parenting or parent-child relations or pregnancy [mh], children of sex workers, commercial sex worker or prostitution) humans

Research on sex workers has concentrated on sexual health, rather than on the broader concept of reproductive and child health. The

Department of Preventive and Social Medicine, SVNGMC, Yavatmal, *BJMC, Pune, Maharashtra, India

\section{Correspondence}

Geeta Pardeshi, VIKAS, Civil lines, Behind Collector's Office, Yavatmal - 445 001, Maharashtra, India

E-mail: geetashrikar@yahoo.com studies and reports on commercial sex workers as a group, have usually focused on their background, plight and profession. ${ }^{[1-3]}$ The interventions for this group are aimed at prevention of spread of HIV (human immunodeficiency) and STDs (sexual transmitted diseases) ${ }^{[4-9]}$ and a few, for empowerment of women. ${ }^{[10-12]}$ Many women who engage in sex work, experience pregnancies and become mothers. 
Unfortunately, very few research studies have examined the challenges faced by the sex workers in raising their children. ${ }^{[13-15]}$ Considering the fact that they are working women with peculiar working patterns and stigma of their profession, this study describes the reasons for child bearing, family support, breastfeeding and child placement options chosen for their children, by brothel- based commercial sex workers in an Indian city.

\section{MATERIALS AND METHODS}

A cross-sectional descriptive study was conducted in the year 2001 in the brothels of Pune city, India. One of the localities of the red-light area was selected, in consultation with a local NGO (non governmental organization). The peer workers enumerated all the brothels in the locality. Out of these, thirty were selected by a simple random sampling method. The data was collected using quantitative and qualitative methodology. Ethical clearance was sought for the study, from the institutional ethical committee. The interviews were conducted in the office of a local NGO located in the redlight area, ensuring privacy and confidentiality, after an oral informed consent was taken. Two women from each of the selected brothels were contacted for collecting preliminary data, using a pre-tested structured questionnaire. The brothel- based sex workers who had borne children in sex work, were selected for in-depth interviews. Each interview was conducted for one to one and a half hours. Key informants like one local leader, two brothel managers and two peers were also interviewed on the topics of difficulties the sex workers experience, while raising their children.

A few brothels were visited to observe their living conditions and environment. Transcripts from the interview were prepared. Analysis was done by calculating proportions and by Chi square test and Fisher's exact test.

\section{RESULTS}

A total of sixty women were contacted for the interviews. All agreed to participate in the study. They included Devdasis from Karnataka (25), women from Nepal (20) and 'others' from states like Maharashtra and Andhra Pradesh (15). The socio-demographic profile of the women is described in Table 1.

\section{Conception and continuation of pregnancy}

Out of the 60 women, 49 had experienced one or more pregnancies. Of these, 35 women reported 73 pregnancies in sex work, of which 37 resulted in live births, 2 stillbirths and in 34 instances, the women underwent an MTP. Out of the 37 children born in sex work, six died in infancy. The reasons for these deaths

Table 1: Socio-demographic characteristics of sex workers

\begin{tabular}{lcc}
\hline Characteristics & Category & $N=60(\%)$ \\
\hline Age & $<20$ years & $2(3.3)$ \\
& $21-29$ years & $28(46.7)$ \\
& 30 to 39 years & $28(46.7)$ \\
Literacy status & 40 years and above & $2(3.3)$ \\
& Illiterate & $57(95)$ \\
Native place & Literate & $3(5)$ \\
& Karnataka & $25(41.7)$ \\
& Nepal & $20(33.3)$ \\
& Others & $15(25)$ \\
\hline
\end{tabular}

could not be ascertained, as no records were available and the women were not able to recount the incidents accurately. A total of 21 live births occurred outside sex work before the women entered the profession.

We enquired about the reasons for bearing children, in 30 women who continued their pregnancy in sex work. Three women were compelled to continue the pregnancy as they had not used any contraception and had reported late for medical termination. This was either because of sheer ignorance or an attempt to hide the fact due to fear of an angry response from the brothel owner.

After entry into sex work, the women did not want to have children in the initial years. However, as their age advanced, they started worrying about their future.

'We want somebody to call as our own.'

'I hoped that my child will grow up and help me get out of this place.'

'Who will perform the religious rites after my death'?

The women usually decided to continue the pregnancy and have children, with hopes of security and support. Twenty-three women did not specify who the partner was, when they conceived the child. A total of nine women developed a fixed relationship with one of the customers and conceived a child.

In all instances, the partner left the woman even before the child was born. A woman narrated:

'I developed an emotional intimate relationship with one of the customers who visited me regularly. I decided to settle down with him and in the process, conceived his child. He however left me, forcing me to return to my profession.'

\section{Breast-feeding and dietary habits}

Out of the 37 babies born in sex work, 24 children had been breast-fed for one year or more than one year and four were never breast-fed [Table 2]. Some of these women also had a peculiar outlook towards themselves. One woman felt that she was not pure and pious. She had delivered a baby girl and had decided not to breast- feed the baby.

'All sorts of customers visit me and touch my body. Some of them are very dirty. I will transmit diseases to my child. I do not want to harm my child."

The Devdasis breast-fed their babies for a longer duration, as compared to the other women.

As the children grew, no special weaning food was prepared for them. They were given top milk and then they shared the food cooked for other brothel residents. In the

Table 2: Duration of breast feeding in children born in sex work
\begin{tabular}{lccc}
\hline Category & Family support available N (\%) & No family support $N(\%)$ & Total $N(\%)$ \\
\hline Devdasis & $12(70.6)$ & $5(29.4)$ & $17(100)$ \\
Others & $1(7.7)$ & $12(92.3)$ & $13(100)$ \\
Total & $13(43.3)$ & $17(56.7)$ & $30(100)$
\end{tabular}

$P<0.001$, Significant difference

nn
te
o
to

4
or
r
n
s
ot
ir
y.
ny
ill
$n t$


morning, breakfast was purchased from a local vendor. A hired cook or the women themselves cooked the meals for the whole day in the afternoon. The children ate their food whenever they felt hungry. In addition, many children were given pocket money to buy eatables. As the brothels were located within the market place, the children purchased cold drinks and food items from the local shops. Once in a week, nonvegetarian food in the form of meat, chicken or fish was prepared in many brothels. A major proportion of the daily earnings were spent for purchasing food for the children in the brothels.

\section{Family support [Table 3]}

The child-rearing practices were found to be related to the kind of social support the women had. The Devdasis maintained a good relationship with their parents and other relatives in their native villages; the other women were completely alienated from their families.

A total of seventeen women were Devdasis. A Devdasi is a woman dedicated to the service of god as a custom or to avoid evil. They had social sanction and experienced less social stigma. They had family support in their native villages. During their pregnancy, these women usually stayed in the brothels and worked up to the fourth to fifth month of

gestation and then went to their native villages. Their families looked after them. After giving birth to the child, they stayed back for six months to as long as one year. However, once they returned back to the brothel, their families, usually their mothers or sisters looked after the child. The main responsibility of providing financial support for raising the child, was with the sex worker. She had to regularly send money to her family. She visited her children once or twice in a year. The children were told that their mother works as a maid or shop vendor in the city.

In other cases, the women had no family to support them. They had to stay back in the brothel. These women continued to entertain clients late in the pregnancy. Some reported working up to the eight-month of gestation. After delivery too, they had to resume work earlier. The women had to entertain the customers in the night, were tired and took rest in the daytime and faced hardships while raising their children.

One of the women had appointed a servant to look after her daughter. She had rented a room in the local area away from the brothel. She visited her daughter during the daytime.

'I want to keep her away from this dirty environment and at the same time, look after her well.'

Table 3: Family support for women with children born in sex work

\begin{tabular}{lccc}
\hline Duration of breast feeding & Devdasis $N(\%)$ & Others $N(\%)$ & Total $N(\%)$ \\
\hline$<6$ months & $0(0)$ & $4(21.1)$ & $4(10.8)$ \\
Up to one year & $5(27.8)$ & $7(36.7)$ & $12(32.4)$ \\
More than one year & $12(66.7)$ & $0(0)$ & $12(32.4)$ \\
Currently breast feeding & $1(5.6)$ & $4(21.1)$ & $5(13.6)$ \\
Not breast fed & $0(0)$ & $4(21.1)$ & $4(10.8)$ \\
Total & $18(100)$ & $19(100)$ & $37(100)$ \\
\hline
\end{tabular}

Servants or ex-sex workers looked after the children kept in the brothels.

\section{Child placements}

Out of the 21 children born prior to entry into sex work, six were sent to hostels and 15 were with their families in the native villages. Out of the 31 children born in sex work who had survived, twelve children were being raised in the brothel [Table 4]. These included four infants and eight children, in the one to five years age group. The children were kept in the brothels up to five years of age. As the children start growing, the women consider various options of keeping them away from the brothel area and so send them to local hostels and rehabilitation centers. Some of the local NGOs were running a residential school for the children of the sex workers. The key informants reported that the women faced difficulties in getting school admissions for their children e.g., nonavailability of birth certificate, residential address proof, father's name etc. The peer workers, along with a local NGO, helped the women in completing all the formalities to get admissions in the institutions. The children of the Devdasis were usually kept at the native village and raised by the family. The mothers had to bear the responsibility of providing monetary support for their children.

The mothers yearned to meet their children. Table 4: Child placement options

\begin{tabular}{lcc}
\hline Placements & Children born during sex work $N^{*}(\%)$ & Children born prior to entry into sex work $N(\%)$ \\
\hline Brothels & $12(39)$ & $0(0)$ \\
Hostel & $7(22)$ & $6(29)$ \\
Family in village/married & $12(39)$ & $15(71)$ \\
Total & $31(100)$ & $21(100)$ \\
\hline
\end{tabular}

*Six children had died in infancy.

d.f. $=2, X^{2}=10.8, P<0.05$.

Indian J Med Sci, Vol. 60, No. 7, July 2006
The children in the hostels and native villages were visited twice or thrice a year, but the women had to hide their identity as sex workers. The women also married off their daughters as early as possible. Four of the respondents had married of their daughters as soon as they attained puberty [Table 4].

Work schedule and brothel environment

Most of the women had fixed daily routine. Some worked only at night, some during the day too. They woke up late in the morning, after working throughout the night. The women took rest for the rest of the day till evening, when they had to get ready for work. A total of $39(65 \%)$ women had one or more addictions, which included smokeless forms of tobacco, cigarette smoking and alcoho consumption.

The investigators visited the brothels in the afternoons when the women were relatively free. Women from a particular native place usually stayed in one brothel i.e., there were brothels where the majority of the women were Devdasis. In some other brothels, al women were from Nepal. The brothe manager also usually belonged to the same native place. The other women helped the mothers look after the child.

"We are all like sisters, help each other and share our sorrows and difficulties" 
The brothel provided shelter, access to means of water and sanitation for the children. The brothels were unclean shanties. They were one or two-storied buildings with narrow staircases. The rooms were overcrowded, ill-ventilated, poorly lighted and divided into small compartments with partitions. There was a constant hustle of customers, vendors and pimps in the brothels. Some women stood outside on the streets, soliciting customers. There were no separate rooms for children. The children were observed to be playing on the streets outside the brothels. The children usually slept in the brothel manager's room at night.

\section{DISCUSSION}

The commercial sex workers conceived and decided to have a child under different circumstances. A few had children due to ignorance about contraceptives and MTP, but many decide to continue the pregnancy, as they wanted children. Some of them develop a fixed relationship with a partner, but eventually all have to function as single parents for their children. Such relationships have been described in other studies, which have focused on condom use in the sex workers. ${ }^{[15,16]}$ These were men who began as clients and then formed long-term relationships. Women need these companions for emotional and practical reasons and are tied to these relationships. However, in a majority of the cases, such relationships were noted to last for a few years, after which the male partner left the women. Thus, as mothers, the brothel-based commercial sex workers were functioning as single parents, shouldering the responsibility of providing financial support, decisionmaking and providing care to her children.

All the sex workers were immigrants to the city and the kind of family support they received, varied according to their background. The Devdasis received more family support in raising their children. The differences in socio-behavioral characteristics and practice patterns between Devadasis and other female sex workers have been documented. ${ }^{[17]}$

In a survey conducted under the Sonagachi project in Calcutta, half of the children were being raised in the brothel where some mothers were paying the older sex workers to raise their children, while others were arranging makeshift crèches when working. Many of the children were being raised outside the brothels, either with the family or in an orphanage. In this survey, less than $5 \%$ children were being raised in an NGO or government run hostel. Ninety percent of the women were financing their children. A high proportion of children in our study were in the native place or in institutions. This can be attributed to the large number of Devdasis in the study sample and the fact that a local NGO was running a residential school for these children. In addition, the peer workers along with another NGO based in the red light area, were motivating and helping the sex workers get the children admitted to schools.

The difference in the support affects the breastfeeding practices, role and responsibilities of the women. While the main responsibility of the Devdasis is to provide financial support to the children who are raised at home, the non-devdasi women have to earn as well as raise the children in the brothels. Though the sample of women as a whole, was a heterogeneous group within each brothel, there was homogeneity with respect to the native place, language, etc, which resulted in providing a supportive network for the women.

The peculiar working schedule of the sex worker, in which she is busy by night and tired in the daytime, also posed problems. Day care centers and night shelters should be made available for children being raised in the brothels. The stigma of being a sex worker makes it invariable for them to send the children to an institution, which is an attempt to keep the children away from the brothel environment and also to hide their identity as a sex worker. Admissions in residential schools along with special rehabilitation centers, will help the children to integrate with the mainstream society in the future. The role of non-governmental organizations and local peers was found to be very important in the rehabilitation of the children of sex workers.

Being a single parent, stigma of the profession, odd working hours and variable family support were major challenges identified. The fact that the women were earning and were financially independent, availability of rehabilitation centers, the homogeneous groups within the brothels, supportive peers and organizations working in the area, were factors which helped them raise their children.

The commercial sex workers dream of a bright future for their children. They should be supported and guided to make this dream a reality, at all costs.

\section{ACKNOWLEDGMENT}

We acknowledge the support given by the FORD Foundation and School of Health Sciences, University of Pune, for conducting this study.

\section{REFERENCES}

1. Chattopadhyay M, Bandyopadhyay S, Duttagupta C. Biosocial factors influencing women to become prostitutes in India. Soc Biol 1994;41:252-9.

2. Mukhopadhyay KK. Girl prostitution in India. Soc Change 1995;25:143-53.

3. Somaiya PA, Awate RV, Bhore PD. Sociopsychological study of the prostitutes. Indian Public Health 1990;34:93-7.

4. Sarkar K, Bal B, Mukherjee R, Niyogi SK, Saha MK, Bhattacharya SK. Epidemiology of HIV infection among brothel-based sex workers in Kolkata, India. J Health Popul Nutr 2005;23:231-5.

5. Bhave G, Lindan CP, Hudes ES, Desai S, Wagle $\mathrm{U}$, Tripathi SP, et al. Impact of an intervention on HIV, sexually transmitted diseases and condom use among sex workers in Bombay, India. AIDS 1995;1:21-30.

6. Gangopadhyay DN, Chanda M, Sarkar K, Niyog SK, Chakraborty S, Saha MK, et al. Evaluation of sexually transmitted diseases / human immunodeficiency virus intervention programs fo sex workers in Calcutta, India. Sex Transm Dis 2005;32:680-4.

7. Basu I, Jana S, Rotheram-Borus MJ, Swendeman D, Lee SJ, Newman P, et al. HIV prevention among sex workers in India. J Acquir Immune Defic Synd 2004;36:845-52

8. Chattopadhyay A, McKaig RG. Social developmen of commercial sex workers in India: An essentia step in HIV/AIDS prevention. AIDS Patient Care STDS 2004;18:159-68. 
9. Jana S, Singh S. Beyond medical model of STD intervention-Lessons from Sonagachi. Indian $\mathrm{J}$ Public Health 1995;39:125-31.

10. Bandyopadhyay N, Banerjee B. Sex workers in Calcutta organize themselves to become agents for change. Sex Health Exc 1999;2:6-8.

11. Jana S, Basu I, Rotheram-Borus MJ, Newman PA. The Sonagachi Project: A sustainable community intervention program. AIDS Educ Prev 2004;16:405-14.

12. Nag M. Sex Workers in Sonagachi Pioneers of a Revolution. Eco Politic Wkly 2005;40:5151-5.

13. Das D. Giving the children of prostitutes their due. ICCW News Bull 1991;39:31-7.

14. Chege MN, Kabiru EW, Mbithi JN, Bwayo JJ. Childcare practices of commercial sex workers. East Afr Med J. 2002;79:382-9.
15. Jenkins C. Female Sex workers, HIV prevention projects: Lessons learnt from Papua New Guinea, India and Bangladesh. UNAIDS 2000;57-88.

16. Evans Cartin, Lambert Helen. An ethnographic study of sexual health and related health seeking behaviour among commercial sex workers and poor women in a northern Calcutta slum. re/productions. 1999;2. [cited 2006, May 1] Available at: http://www.hsph.harvard.edu/ organizations/healthnet/SAsia/repro2/ ETHNOGRAPHY.htm

17. Blanchard JF, O'neil J, Ramesh BM, Bhattacharjee $P$, Orchard T, Moses S. Understanding the social and cultural contexts of female sex workers in Karnataka, India: Implications for prevention of HIV infection. J Infect Dis 2005;91:139-46. 